Omni-Akuatika, 14 (3): 18-25, 2018
ISSN: 1858-3873 print / 2476-9347 online
Research Article
journal homepage: http://ojs.omniakuatika.net

\title{
Detection of Eutrophication in Benoa Bay - Bali
}

\author{
Yulianto Suteja $^{1^{*}}$, I Gusti Ngurah Putra Dirgayusa ${ }^{1}$ \\ ${ }^{1}$ Marine Science Department, Faculty of Marine Science and Fisheries, Udayana University, \\ Jl. Kampus Bukit Jimbaran, Badung, Bali, Indonesia \\ ‘Corresponding author: yuliantosuteja@unud.ac.id
}

Received 24 July 2018; Accepted 25 September 2018; Available online 30 November 2018

\begin{abstract}
Eutrophication is an increase of organic material caused by the increase of nutrients in aquatic ecosystem by human activities. One effect of eutrophication is Harmful Algae Blooms (HABs) that are very harmful to the environment and humans. The Purpose of this study were determine spatial distribution of nutrient based on total nitrogen (total $\mathrm{N}$ ) and total phosphate (total $\mathrm{P}$ ), ratio of total $\mathrm{N}$, and trophic level in Benoa Bay. Nutrient measurements were using spectrophotometric method. The Spatial distribution of total $\mathrm{N}$ and $\mathrm{P}$ show a generally pattern concentration increases in waters near the mainland and estuary. The highest concentrations of total $\mathrm{N}$ and $\mathrm{P}$ were found in Loloan River estuary closed to the floating net cages (FNC). Ratio of total $\mathrm{N}$ showed generally that the waters in Benoa Bay were dominated by Nitrate. High ammonia concentration was found in all rivers and Loloan River estuary. Benoa Bay is mostly in Oligotrophic conditions based on total N, while eutrophic conditions were only found in the Loloan River estuary. Based on total P, Benoa Bay was generally in hypertrophic level.
\end{abstract}

Keywords: Harmful algae blooms, nutrient, total $N$, total $P$, eutrophic

\section{Introduction}

Eutrophication is one of the problems in the world, especially in developing countries (Yang et al., 2008). Eutrophication is an increasing of organic material caused by the addition of nutrients in an aquatic ecosystem by human activities (Nixon, 1995). Human activities such as urbanization, industrialization, waste disposal, aquaculture and intensive agriculture are activities that accelerate nutrient concentration in waters (Anderson et al., 2002; Liu and Qiu, 2007; Diaz and Rosenberg, 2008). One of the harmful effects of eutrophication is Harmful Algae Blooms (HABs) or better known as red tide (Anderson et al., 2002).

HABs is an increase in the abundance of phytoplankton (algae) in aquatic ecosystems that can cause death due to toxicity or anoxia conditions in water (GEOHAB, 2001). HABs are not only harmful to marine organisms, but also harmful to humans who consume fish that contain toxins from HABs. Toxins usually accumulate in body tissues of organisms (Wardianto et al., 2004; Anderson et al., 2008). Some diseases caused by HABs such as paralytic shellfish poisoning (PSP), neurotoxic shellfish poisoning (NSP), amnesic shellfish poisoning (ASP), and ciguatera fish poisoning (CFP) (Anderson et al., 2008). In some cases, HABs cause of humans death (Wardianto et al., 2004). According to Widiarti and Pratiwi (2003), several cases of poisoning from consuming shells infected by HABs have occurred in Lewotobi and Lewouran (East Nusa Tenggara), Sebatik Island (East Borneo), Makassar Waters and Ambon Bay.

In Indonesia, HABs cases characterized by eutrophic or hypertrophic conditions occur in Jakarta Bay and Lampung Bay (Damar 2003; Wardianto et al., 2004; Irawan, 2015). The conditions that support the occurrence of eutrophication in bay waters are calm currents, small waves, high nutrient input, and environmental factors (such as temperature, salinity, $\mathrm{pH}$ etc.) that support the phytoplankton life of (Zhao, 2004; Cai et al., 2007; Roy et al., 2013). Turner and Rabalais (1991) explained that the bay is area that gets the most nutrient input from the mainland. Nutrient is a major factor that limiting the phytoplankton growth in aquatic ecosystem under normal conditions. 
Early detection of eutrophication characterized by nutrient enhancement is the first step to detect HABs.

Benoa Bay is an estuary of six rivers in Bali such as Buaji, Sama, Mati, Badung, Bualu and Loloan Rivers. Previous research conducted by Suteja and Purwiyanto (2018) showed nutrient input (nitrate and phosphate) from six rivers to the Benoa Bay is very high and potential to trigger eutrophication. Besides that, Benoa Bay is also characterized by a weak current (Hendrawan and Asai, 2014) thereby increasing the potential for eutrophication. In addition, Benoa Bay is utilized by fishermen as fishing zone (for fish and shellfish) and cultivation zone. If HABs occur in Benoa Bay and people consume fish caught from this area, it will endanger human health. The similarities characteristic between Benoa Bay with Lampung and Jakarta bay have potential for eutrophication and HABs occurring. The purpose of this study were determine spatial distribution of nutrient based on Total $\mathrm{N}$ and $\mathrm{P}$, ratio of total $\mathrm{N}$, and trophic level in Benoa Bay.

\section{Materials and Methods}

\subsection{Study site}

This study was conducted for 4 months with sampling in July 2017 (dry season). The study sites were conducted in Benoa Bay with 30 sampling points (Figure 1). 6 points in this study were in the river and 26 points in Benoa Bay. The location of this study is adjacent to the I Gusti Ngurah Rai Bali international airport and Ngurah Rai forest park (Taman Hutan Raya Ngurah Rai).

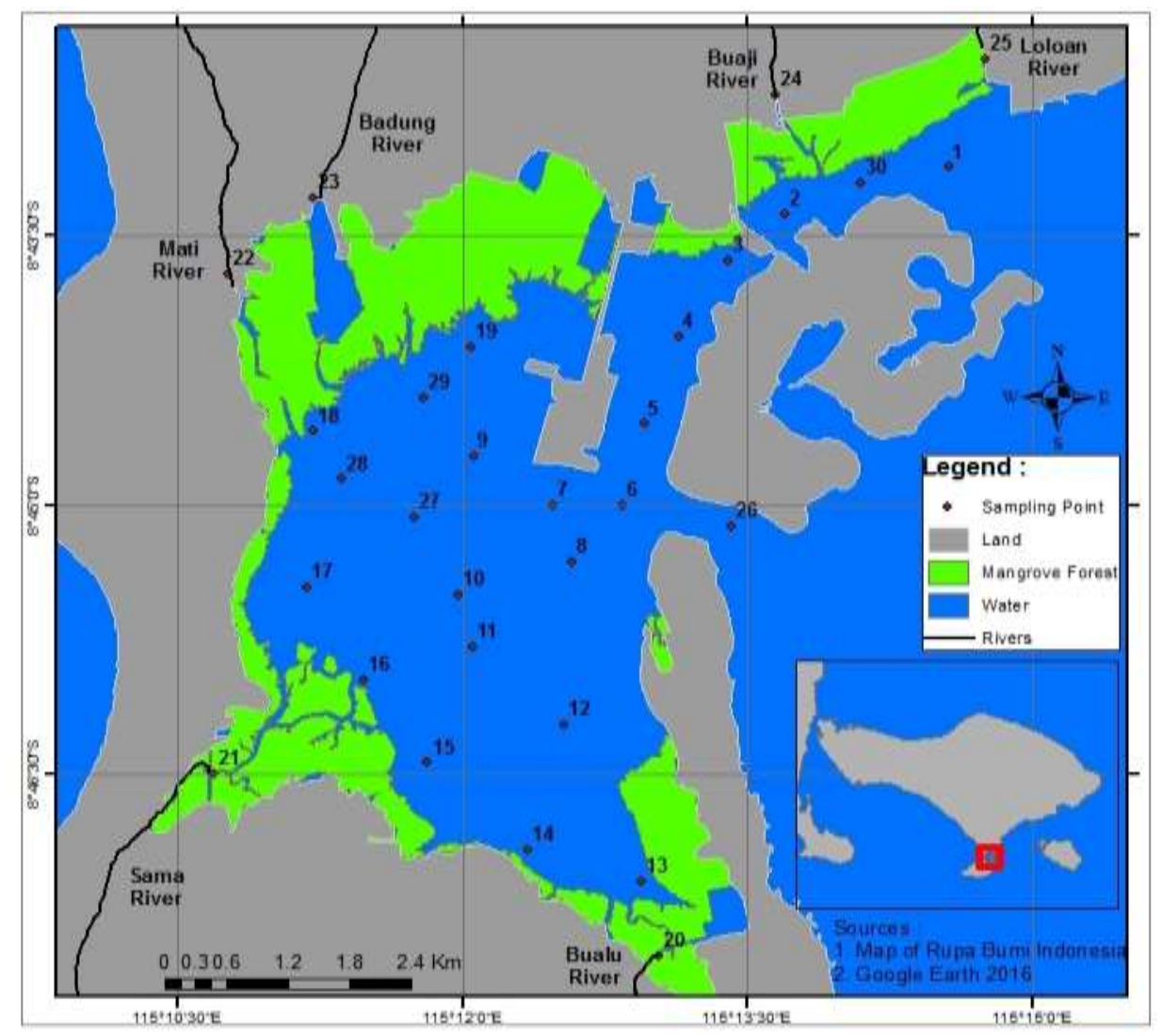

Figure 1. Map of sampling location in Benoa Bay.

\subsection{Samples collection}

Sample measurements in this study were divided into direct and indirect measurements. Direct sample measurement is the measurement of dissolved oxygen (DO) with DO meter (expressed in $\mathrm{mg}^{-1} \mathrm{~L}^{-1}$ ) which will be useful to know the cause of different composition of nitrate, nitrite and ammonia. Indirect measurements were made by taking 1.5 liters of water at each sampling point. Water sampling was done by using Kemmerer water sampler at flood to ebb tide condition. The water samples obtained were then inserted into 
the bottle and stored in a cool box filled with ice cubes. Water samples were then taken to the Analytical Laboratory of Udayana University for measurement of nitrate, nitrite, ammonia, and phosphate.

\subsection{Nutrient measurement}

Measurements of nutrient concentration were using spectrophotometric method (detection limit 0.001) according to Standar Nasional Indonesia (SNI). Nitrate, nitrite, ammonia and phosphate content were respectively based on SNI 06-2480-1991, SNI 06-6989.9-2004, SNI 06-6989.30-2005, and SNI 06-6989.31-2005. Nutrient concentrations were expressed in $\mathrm{mg} . \mathrm{L}^{-1}$.

\subsection{Data analysis}

Total $\mathrm{N}$ in this study was calculated from the summation between nitrate, nitrite and ammonia (Total Inorganic Nitrogen/TIN) without calculating Total Organic Nitrogen (TON). The data that have been obtained was processed by using Microsoft Excel and mapped spatially. The ratio of total $\mathrm{N}$ was obtained by using the percentage of nitrate, nitrite and ammonia content in each station. The trophic level in Benoa Bay refers to Richardson et al. (2007) (Table 1).
Tabel 1. Category of trophic level based on Total $\mathrm{N}$ and $\mathrm{P}$

\begin{tabular}{lcc}
\hline $\begin{array}{c}\text { Trophic level } \\
\text { category }\end{array}$ & $\begin{array}{c}\text { Total N } \\
\left(\mathrm{mg}^{-1}\right)\end{array}$ & $\begin{array}{c}\text { Total } \mathrm{P} \\
\left(\mathrm{mg} . \mathrm{L}^{-1}\right)\end{array}$ \\
\hline Oligotrophic & $0.25-0.5$ & $0.005-0.01$ \\
Mesotrophic & $0.500-1$ & $0.01-0.03$ \\
Eutrophic & $1-2$ & $0.03-0.1$ \\
Hypertrophic & $>2$ & $>0.1$ \\
\hline
\end{tabular}

\section{Results and Discussion}

\subsection{Total $\mathrm{N}$}

The Total $\mathrm{N}$ measurement results in Benoa Bay show that the concentration varies on each station (Figure 2). The lowest of total $\mathrm{N}\left(0.089 \mathrm{mg} . \mathrm{L}^{-1}\right)$ was found in station 10 located in the middle of Benoa Bay, while the highest concentration (16.25 mg. $\mathrm{L}^{-1}$ ) was found at station 25 located in Loloan River. The highest concentration of Total $\mathrm{N}$ in Loloan River is thought to be due to intense waste disposal. This can be seen from the visual observations made in the Loloan River during sampling process. The similar result in January also obtained by Rahayu et al. (2018) in Loloan River, but different from that obtained by Suteja and Purwiyanto (2018) who get the highest nitrate concentration in Buaji River.

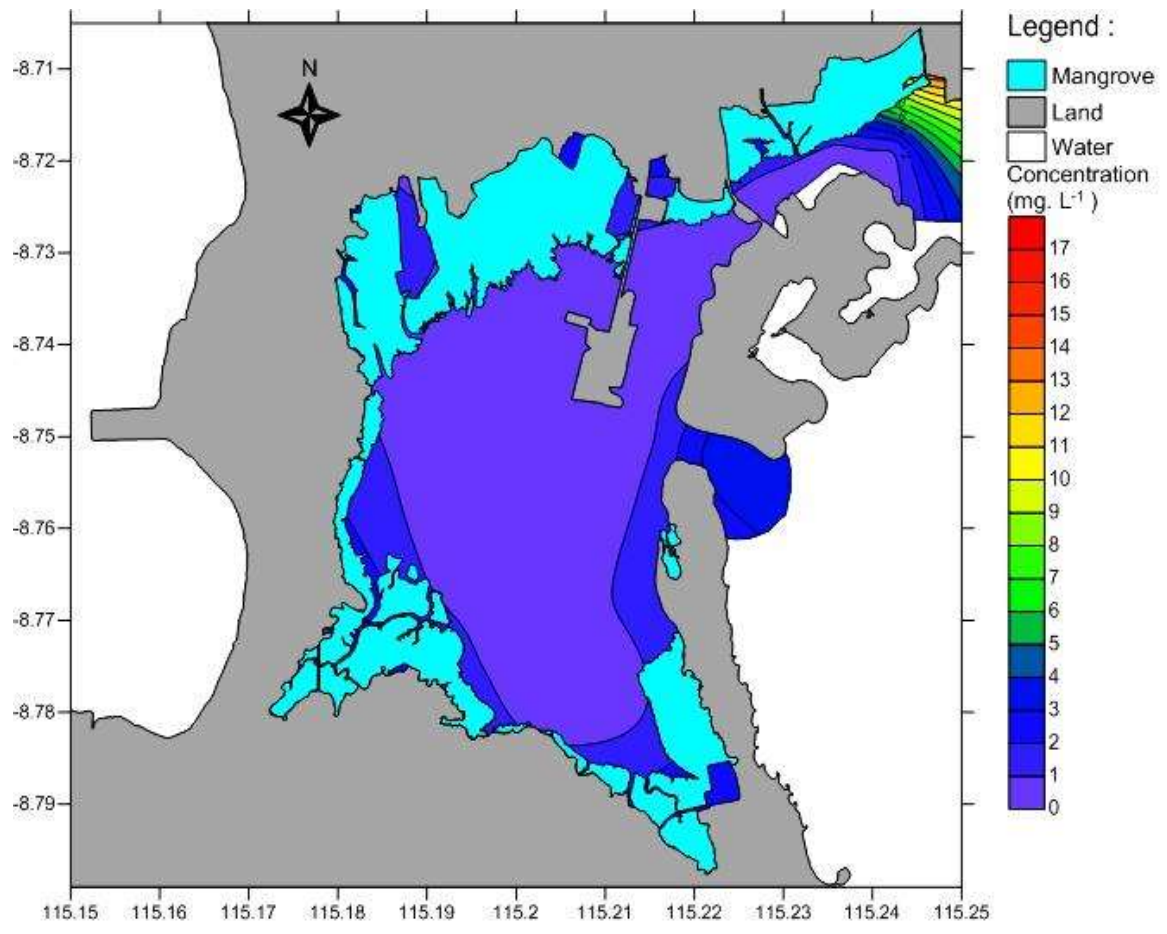

Figure 2. The spatial distribution of total N in Benoa Bay. 
Spatially, the highest concentration of Total $\mathrm{N}$ was in the Loloan River estuary. The high concentration of Total $\mathrm{N}$ at the Loloan River estuary was allegedly by the activity of Floating Net Cages (FNC) which is found around the location and high input from the Loloan River. Described by Mansur et al. (2013) that 1 unit of FNC can produce $243.9 \mathrm{~kg}$ of nitrogen in six months of fish cultivation. It was generally seen that the total $\mathrm{N}$ concentration was high around the land or river estuary and decreases towards the bay's mouth. This pattern was caused by runoff and river flow carrying nitrate, nitrite and ammonia from the land. Inorganic nitrogen in the waters mainly comes from agricultural systems that use fertilizer and carried by the river flow to water ecosystem (Savci, 2012a; Savci, 2012b). The total $\mathrm{N}$ spatial distribution has a similar pattern with nitrate that obtained by Rahayu et al. (2018) in Benoa Bay.

\subsection{Ratio of Total $\mathrm{N}$}

The percentage ratio between Nitrate, Nitrite and Ammonia in Benoa Bay were differs between stations (Figure 3). Overall it was found that nitrate concentrations dominated on each station in Benoa Bay. According to Ruckart et al. (2008) and Purwiyanto et al. (2012) that nitrate was the most stable of nitrogen over time in aerobic water condition.
Ammonia concentrations were found more dominant at stations 1, 26 and 30 than nitrate and nitrite. Stations 1 and 30 were stations that closed to fish cultivation with FNC. Feeding by using pellets and trash fish that were not consumed by the cultivation fish were strongly suspected of contributing highly ammonia concentration. Gorlach-Lira et al. (2013) explained that FNC activities were increase the ammonia content in the water. Nitrogen waste from FNC can be derived from cultivated feed residues and fish feces (Mansur et al., 2013). The high concentration of ammonia at stations 1 and 30 was due to the low dissolved oxygen (DO) at the station (Figure 4). This condition makes denitrification reactions to be dominant. The results of this study were in line with those obtained by Purwiyanto et al. (2012) who get high ammonium concentrations when DO is low in Muara Angke. The high ammonia at station 26 was suspected by the waste disposal carried out by the various activities at the Benoa Harbor. The increasing of ammonia concentration towards the harbor was obtained by Puspitasari and Natsir (2016) at Lembar Harbor in West Nusa Tenggara. Described by Huhta et al. (2007) that waste from toilets and medical facilities on ships can produce $12-15 \mathrm{~g}$ nitrogen per person per day. Wiweska-Bien et al. (2016) added that 182 tons of nitrogen annually only from vessel food waste.

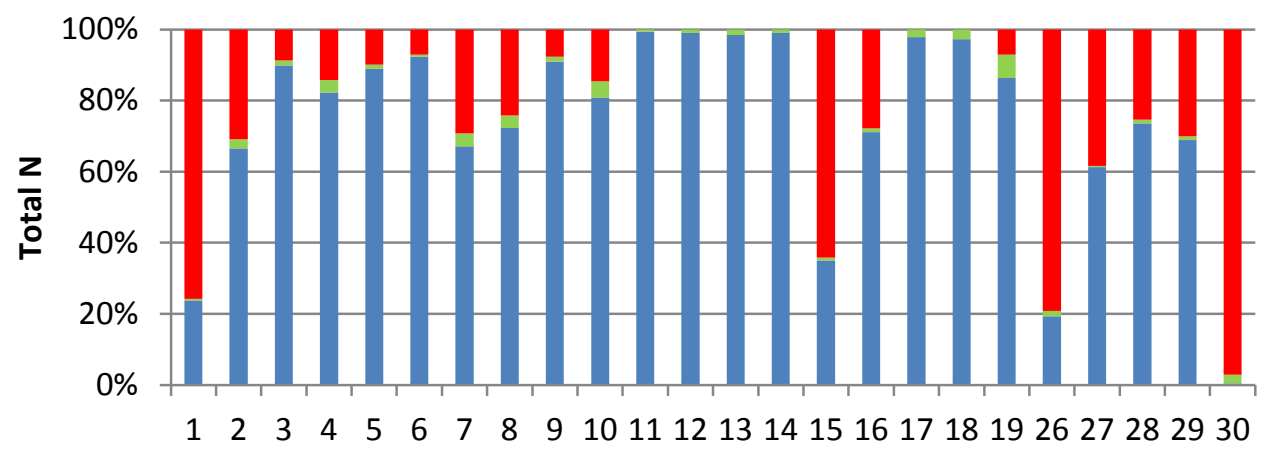

Station

Figure 3. Ratio of Nitrate (blue), Nitrite (green) and ammonia (red) concentration in Benoa Bay.

The ratio of total $\mathrm{N}$ in rivers showed a different pattern than in Benoa Bay (Figure 5). Ammonia concentrations in rivers were more dominant than nitrates. The high concentration of ammonia in the river was suspected by the low DO $\left(3.25-5.15 \mathrm{mg}\right.$. $\left.\mathrm{L}^{-1}\right)$. In addition, the high ammonia was due to the disposal of domestic waste along the watershed to the river. The Ratio of total $\mathrm{N}$ ratio showed only in the Badung River which has more dominant nitrate than ammonia. This is due to the high water discharge that was able to neutralize the incoming waste. Described by Suteja and Purwiyanto (2018) that Badung River was the greatest water discharge compared to other rivers, but this river gives the second largest water discharge to the Benoa Bay due to dam made by Regional Water Company (Perusahaan Daerah Air Minum/PDAM). The water from Badung River is only channeled to the Benoa Bay when the volume of water in the dam has exceeded the capacity of the dam. 


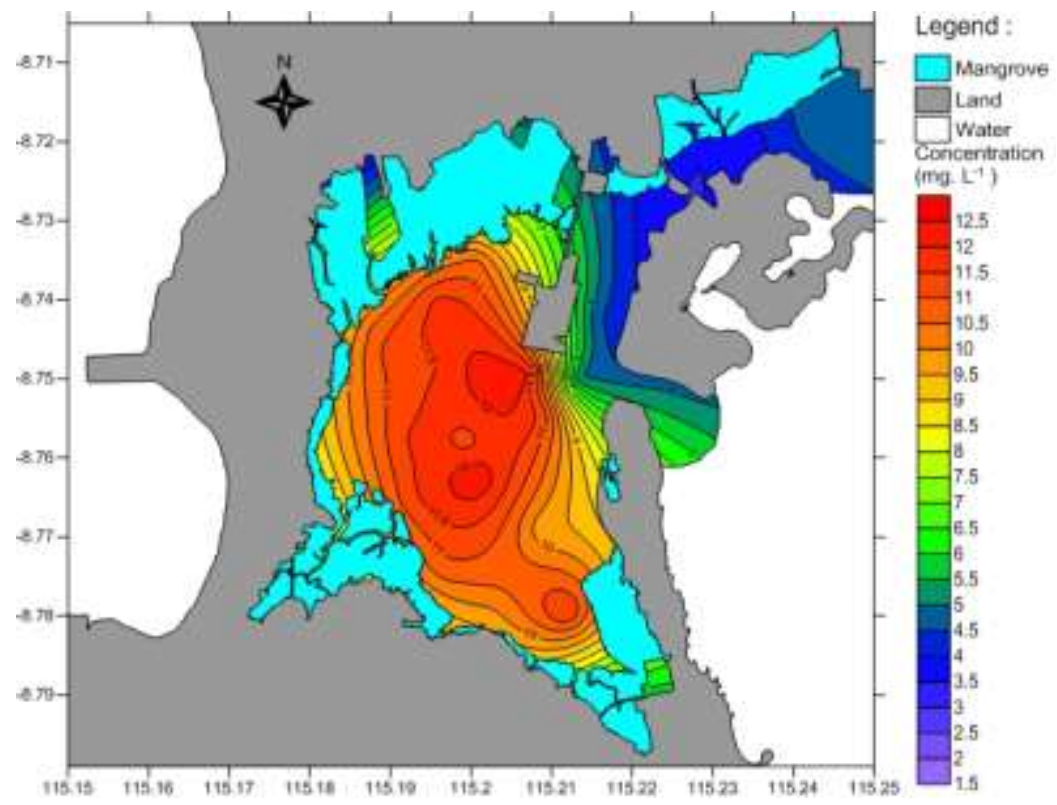

Figure 4. Spatial distribution of DO in Benoa Bay.

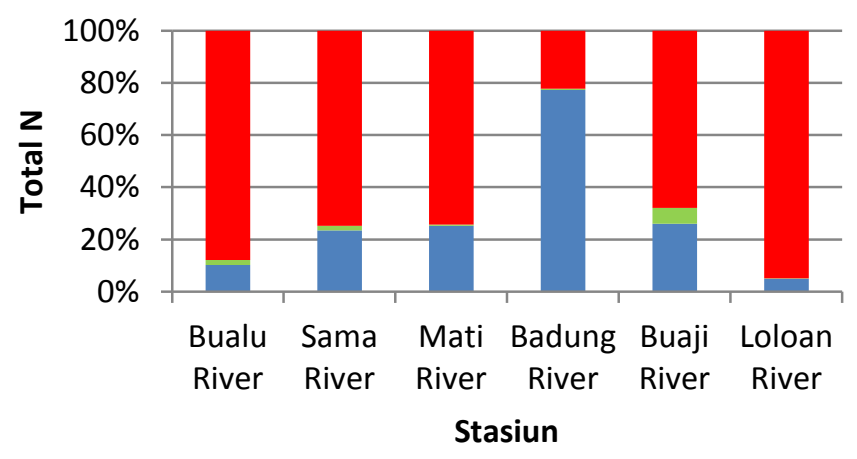

Figure 5. Ratio of Nitrate (blue), Nitrite (green) and ammonia (red) concentration in rivers.

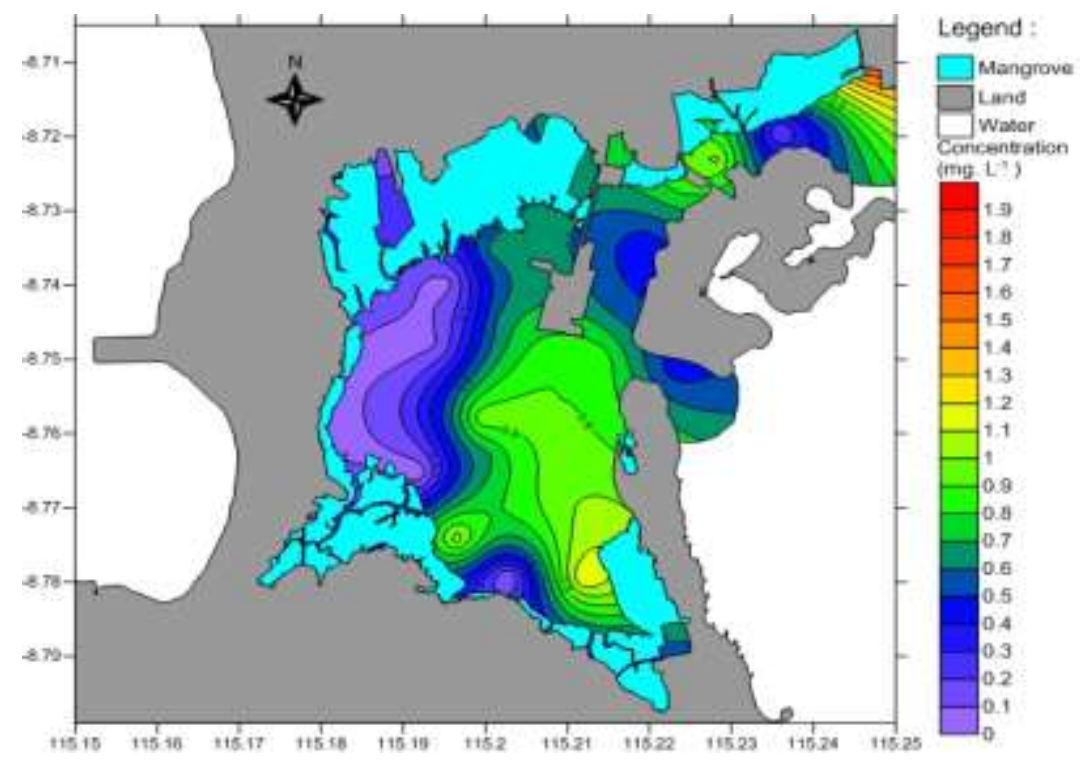

Figure 6. The spatial distribution of total $\mathrm{P}$ in Benoa Bay. 


\subsection{Total $P$}

The total $\mathrm{P}$ concentration in Benoa Bay varies between stations (Figure 6). The average concentration of Total $\mathrm{P}$ in Benoa Bay was $0.5715+0.3768 \mathrm{mg}$. $\mathrm{L}^{-1}$ ranging from $0.0360 \mathrm{mg} \cdot \mathrm{L}^{-1}$ (station 28) to $1,2153 \mathrm{mg} \cdot \mathrm{L}^{-1}$ (station 13). Spatial distribution of Total $P$ in the Benoa Bay showed that its concentration increases in the coastal area of Benoa Cape and decreases progressively towards the middle of the bay. This is assumed by the waste disposal derived from community activities (hotels, settlements, etc.) located around Benoa Cape. Spatial distribution of Total $P$ in the west side of Benoa Bay (estuaries of the Dead River, Sama River and Badung River) showed an increase concentration towards the middle of the bay. This is assumed by the presence of phosphate dilution by the high freshwater input from Mati and Badung Rivers. Badung and Mati Rivers were the largest provide freshwater input to the Benoa Bay (Suteja and Purwiyanto, 2016). The total $\mathrm{P}$ distribution has similar pattern with previous result conducted by Rahayu et al. (2018) in February.

\subsection{Trophic level}

The Trophic level based on total $\mathrm{N}$ and $P$ in Benoa Bay showed that the waters were divided into 4 categories: oligotrophic, mesotrophic, eutrophic and hypertrophic (Figure 7). Benoa Bay generally was in oligotrophic (poor nutrient content) and mesotrophic (moderate nutrient content) based on total N. Eutrophic and hypertrophic was found around Loloan River estuary which was allegedly caused by the high activity of effluent from Loloan River and FNC. hypertrophic conditions were found almost throughout the Benoa Bay based on total P. Mesotrophic and eutrophic conditions were found in front of the Mati and Badung Rivers, this allegedly caused by the Total $P$ dilution by fresh water entering Benoa Bay through the rivers. Further research is needed to measure trophic levels based on plankton abundance and chlorophyll concentrations in the Benoa Bay.

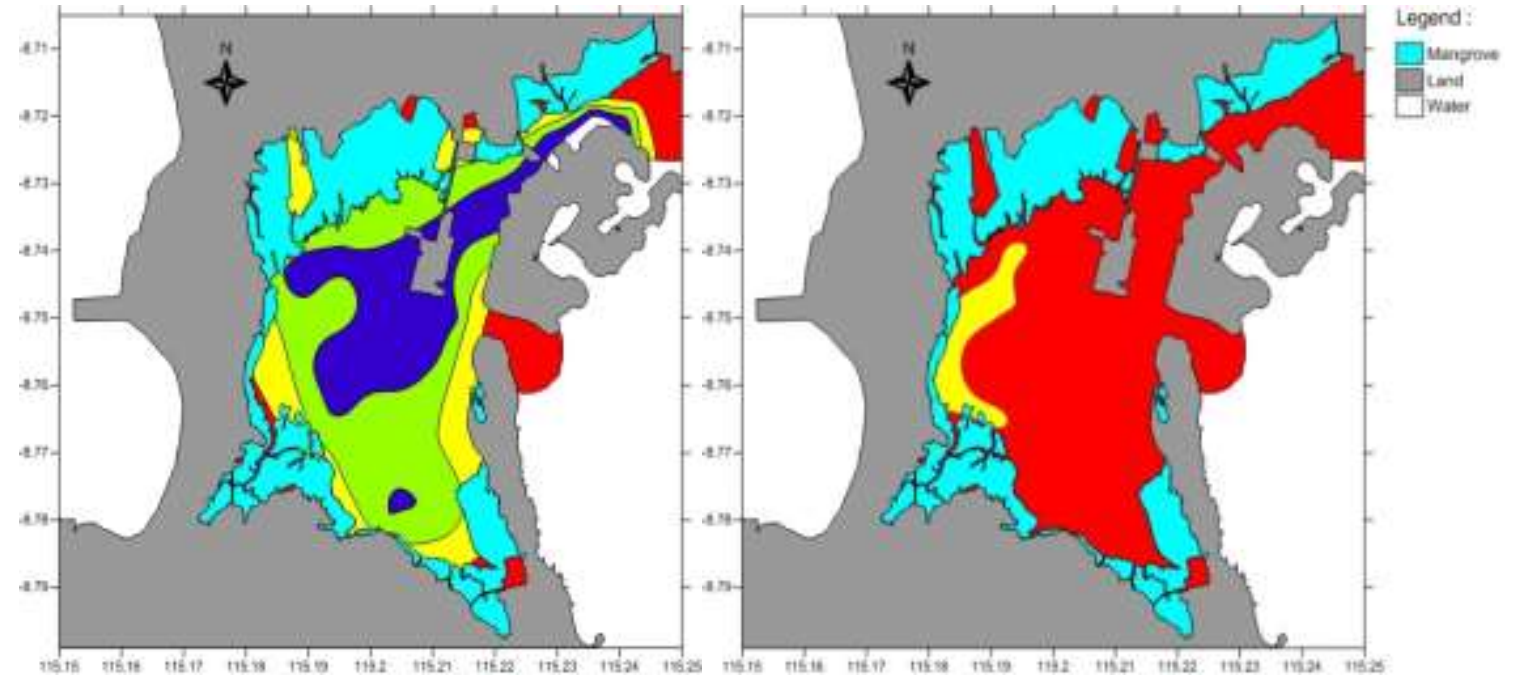

Figure 7. Trophic level in Benoa Bay based on total N (Left) and total P (right) for oligotrophic (blue), mesotrophic (Green), eutrophic (yellow) and hypertrophic (Red).

\section{Conclusion}

The Spatial distribution of total $\mathrm{N}$ and $\mathrm{P}$ show a generally pattern concentration increases in waters near the mainland and estuary. The highest concentrations of total $\mathrm{N}$ and $\mathrm{P}$ were found in Loloan River estuary closed to the FNC. Ratio of total $\mathrm{N}$ showed generally that the waters in Benoa Bay were dominated by Nitrate. High ammonia concentration was found in all rivers and Loloan River estuary. Benoa Bay is mostly in Oligotrophic conditions based on total N, while eutrophic conditions were only found in the
Loloan River estuary. Based on total P, Benoa Bay was generally in hypertrophic level.

\section{Acknowledgement}

The authors are grateful to Udayana University who founded this research in 2017 through HUPS (Hibah Unggulan Program Studi). We also Thanks to Analitik Laboratory staff for their cooperation during nutrient measurement and student who participated in this research. Special thanks to Anna Ida Sunaryo Purwiyanto for her warm discussion. 
The authors also thank to both reviewer who give great suggestion on this paper.

\section{References}

Anderson, D.M., Glibert, P.M., Burkholder, J.M. 2002. Harmful Algal Blooms and eutrophication: nutrient sources, composition, and consequences. Estuaries 25(4b): 704-726.

Anderson, D.M., Burkholder, J.M., Coclan, W.P., Glibert, P.M., Gobler, C.J., Heil, C.A., Kudela, R.M., Parsons, M.L. , Rensel, J.E.J., Townsendi, D.W., Trainer, V.L., Vargo, G.A. 2008. Harmful algal blooms And eutrophication: examining linkages from selected coastal regions of the United States. Harmful Algae 8(1): 39-53.

Cai, J.B., Ding, X.F., Peng, H.Y., Chang, H.Q., Yang, X.E., 2007. Effects of environmental factors and submerged aquatic plants on phosphorus release from the sediment. Journal of Soil and Water Conservation 21(2): 151-154.

Damar, A. 2003. Effects of enrichment on nutrient dynamics, phytoplankton dynamics and primary production in Indonesian tropical waters: a comparison between Jakarta Bay, Lampung Bay and Semangka Bay. Forschungs-und Technoliogiezentrum. Westkueste Publ. Ser : 196 pp.

Diaz, R.J., Rosenberg, R. 2008. Spreading dead zones and consequences for marine ecosystems. Science 321: $926-$ 929.

Hendrawan, IG., Asai, K. 2014. Numerical study on tidal currents and seawater exchange in the Benoa Bay, Bali, Indonesia. Acta Oceanologica Sinica Vol 33(3);90-100.

Irawan, A., Hasani, Q., Yuliyanto, H. 2015. Fenomena Harmful Algal Blooms (HABs) di Pantai Ringgung Teluk Lampung, pengaruhnya dengan tingkat kematian ikan yang dibudidayakan pada Karamba Jaring Apung. Jurnal Penelitian Pertanian Terapan 15(1): 48-53.

GEOHAB (2001) Global ecology and oceanography of harmful algal blooms, science plan. P. Glibert and G. Pitcher (eds). SCOR and IOC, Baltimore and Paris. 100 pp.

Gorlach-Lira, K., Pacheco, C., Carvalho, L.C.T., Melo Júnior, H.N., Crispim, M.C. 2013.
The influence of fish culture in floating net cages on microbial indicators of water quality. Brazilian Journal of Biology 73(3): 457-463.

Liu, W., Qiu, R.L. 2007. Water eutrophication in China and the combating strategies. Journal of Chemical Technology and Biotechnology 82(9): 81-786.

Mansur, W., Kamal, M.M., Krisanti, M. 2013. Estimasi limbah organik dan daya dukung perairan dalam upaya pengelolaan terumbu karang di perairan Pulau Semak Daun Kepulauan Seribu. Depik 2(3): 141-153.

Nixon, S.W. 1995. Coastal marine eutrophication: A definition, social causes, and future concerns. Ophelia 41: 199-219.

Purwiyanto, A.I.S., Prartono, T., Koropitan, A.F. 2012. Vertical distribution and flux of nutrients in the sediments of the mangrove reclamation region of Muara Angke Kapuk, Jakarta. Makara Journal of Science 16(3): 197-202.

Puspitasari, R., Natsir., S.M. 2016. Kualitas lingkungan untuk menunjang budi daya biota laut di Perairan Lombok Barat. Lipi Press: Jakarta. 221pp.

Rahayu, N.W.S.T., Hendrawan, I.G., Suteja., Y. 2018. Distribusi nitrat dan fosfat secara spasial dan temporal saat musim barat di permukaan perairan Teluk Benoa, Bali. Journal of Marine and Aquatic Sciences 4(1): 1-13.

Richardson, C.J., King, R.S., Qian, S.S., Vaithiyanathan, P., Qualls, R.G., Stow, C.A. 2007. Estimating ecological thresholds for phosphorus in the Everglades. Environmental Science and Technology 41(23): 8084-8091.

Roy, K., Chari, M.S., Gaur, S.R. 2013. Eutrophication in lentic systems and its impact on fisheries. International Journal of Research in Fisheries and Aquaculture 3(4): 170-175.

Ruckart, P.Z., Henderson, A.K., Black, M.L., Flanders, W.D. 2008. Are nitrate levels in groundwater stable over time?. Journal of Exposure Science and Environmental Epidemiology 18: 129-133.

Savci, P. 2012a. Investigation of effect of chemical fertilizers on environment. APCBEE Procedia 1: 287-292. 
.2012b. An Agricultural Pollutant: Chemical Fertilizer. International Journal of Environmental Science and Development 3(1): 77-80.

SNI 06-2480-1991. Metode pengujian kadar nitrat dalam air dengan alat spektrofotometer secara brusin sulfat. Badan Standardisasi Nasional.

SNI 06-6989.30-2005. Air dan air limbah Bagian 30 : Cara uji kadar amonia dengan spektrofotometer secara fenat. Badan Standardisasi Nasional.

SNI 06-6989.31-2005. Air dan air limbah Bagian 31 : Cara uji kadar fosfat dengan spektrofotometer secara asam askorbat. Badan Standardisasi Nasional.

SNI 06-6989.9-2004. Air dan air limbah Bagian 9 : Cara uji nitrit $\left(\mathrm{NO}_{2}-\mathrm{N}\right)$ secara spektrofotometri. Badan Standardisasi Nasional.

Suteja, Y., Purwiyanto, A.I.S.P. 2018. Nitrate and phosphate from rivers as mitigation of eutrophication in Benoa Bay, BaliIndonesia. IOP Conf. Series: Earth and Environmental Science 162(012021): 19.

Turner, R.E., Rabalais, N.N. 1991. Changes in Mississippi River water quality this century. Implications for coastal food webs. BioScience 41: 140-147.

Wardiatno, Y., Damar, A., Sumartono, B. 2004. A short review on the recent problem of red tide in Jakarta Bay: effect of red tide on fish and human. Jurnal IImu-IImu Perairan dan Perikanan Indonesia 11(1): 67-71.

Widiarti, R., Pratiwi, T. 2003. IMFS 2003, International Seminar on Marine and Fisheries, Jakarta: 73-78.

Wilewska-Bien, M., Granhag, L., Andersson. K. 2016. The nutrient load from food waste generated onboard ships in the Baltic Sea. Marine Pollution Bulletin 105(1): 359-366.

Yang, X., Wu, X., Hao, H., He, Z. 2008. Mechanisms and assessment of water eutrophication. Journal of Zhejiang University Science B 9(3): 197-209.

Zhao, S.C., 2004. Mechanisms of lake eutrophication and technologies for controlling in China. Advance in Earth Sciences 19(1): 138-140. 